\title{
Innovative materials in winemaking
}

\author{
Camelia Elena Luchian ${ }^{1}$, Cintia Colibaba ${ }^{1}$, Marius Niculaua ${ }^{2}$, Maria Codreanu $^{1}$, and Valeriu V. Cotea ${ }^{1}$ \\ ${ }^{1}$ The University of Agricultural Sciences and Veterinary Medicine, Mihail Sadoveanu Alley, Iaşi 700490, \\ Romania \\ ${ }^{2}$ Research Centre for Oenology - Iaşi branch of Romanian Academy Mihail Sadoveanu Alley, Iaşi 700490, \\ Romania
}

\begin{abstract}
Wineries have been trying to reduce metallic content of wines by adding various substances. The most used treatment with potassium ferrocyanide causes the elimination of the majority of iron content, together with a significant reduction in the content of other metals. Potassium ferrocyanide also leads to the formation of undesirable hazes. White wines composition and organoleptic properties are influenced by many and diverse factors corresponding to the specific production area, such as grape variety, soil and climate, culture, yeast, winemaking practices and storage. The aim of this research was to investigate variations in metals and volatiles content of Feteasca regală wine samples treated with SBA-15, AlMCM-41, KIT-6 and Clinoptilolite materials with GS-MS and MP-AES.
\end{abstract}

\section{Introduction}

Wine is a common alcoholic beverage worldwide consumed and produced, which has been well-known from ancient times. The reasonable consumption of wine was shown to improve health and longevity. In terms of the chemical composition, wine is a complex matrix with a fluctuating content of inorganic compounds (traces of alkaline and alkaline earth metals elements, and transition metals), plus organic substances (acids, esters, polyphenols, polyhydroxy alcohols, proteins, amino acids, and polysaccharides, etc.) dissolved or dispersed in an ethanol aqueous solution [1,2].

Analysis of the metal content in wine is required for the following reasons: firstly, regarding the effect of high concentrations that transition metals might have on the human body, then the influence that some metals $(\mathrm{Cu}$, $\mathrm{Fe}, \mathrm{Mn})$ have on the aromatic profile or on the clarity of wine. The alterations in organoleptic properties lead to the wine rejection, which causes financial problems. The regional variations of the trace metal content in wines can also be used for identification purposes, to verify authenticity $[3,4]$.

Wine producers have for many years been trying to reduce metallic content by adding various substances to the wine. Treatment with potassium hexacyanoferrate (II) causes the reduction of the iron content, together with significant decrease in the content of other metals that also participate in the browning and are highly contaminating ( $\mathrm{Mn}, \mathrm{Cu}, \mathrm{Zn}$, etc.).

Because of toxic effects of this treatment, recent research has start for alternative methods and materials that facilitate the metallic content of the wine to be reduced without altering its composition.
Aroma and flavor compounds of wines have been studied broadly over the last 20 years, and analyses of these work on aroma and flavor list hundreds of volatile substances detected in red or white wines. The concentration of these volatile substances is essential to the identity and complexity of wine [5].

The compounds classes found in wine include esters, alcohols, acids, lactones, carbonyl compounds, acetals, phenols, sulfur containing volatiles, nitrogen-containing volatiles. The basic aroma of white wine can be attributed to four esters (ethyl acetate, isoamyl acetate, ethyl caproate and caprylate), two alcohols (isobutyl alcohol, isoamyl alcohol) and acetaldehyde.

The synthesis of micro and mesoporous porous materials, defined by IUPAC as materials with pore sizes between 0.2 and $50 \mathrm{~nm}$, is an active segment of research. These materials contain a regular framework supporting a regular, porous structure.

The exploration of compositions and structures for micro and mesoporous materials in view of specific applications in the oenological area as sorption and separation support, has led to considerable results, reported in literature $[6,7]$.

To continue research on the effect of some innovative materials on wine composition, were analyzed Feteasca albă white wine samples treated with micro and mesoporous materials.

The aim of this research was to investigate variations in metals and volatiles content of Feteasca regală wine samples treated with SBA-15 [8], AlMCM-41 [9], KIT-6 $[10,11]$ and Clinoptilolite materials [12].

The wines were bottled and stored for 12 months in contact with the micro- and mesoporous materials and then analyses were performed. 
Table 1. Molar composition of the synthesis gel.

\begin{tabular}{|c|c|}
\hline AlMCM-41 & $1 \mathrm{SiO}_{2}: 0.033 \mathrm{Al}_{2} \mathrm{O}_{3}: 0.2 \mathrm{C} 16 \mathrm{TMABr}: 100 \mathrm{H}_{2} \mathrm{O}$ \\
\hline MCM-41 & $1 \mathrm{SiO}_{2}: 0.2 \mathrm{C}_{16}$ TMAB: $5.7 \mathrm{NH}_{3}: 113 \mathrm{H}_{2} \mathrm{O}$ \\
\hline SBA-15 & $1 \mathrm{SiO}_{2}: 0.017 \mathrm{P} 123: 5.87 \mathrm{HCl}: 194 \mathrm{H}_{2} \mathrm{O}$ \\
\hline KIT-6 & $\begin{array}{l}\text { 0.017 P123: } 1.3 \text { TEOS: } 1.31 \text { BuOH: } 1.83 \mathrm{HCl} \text { : } \\
195 \mathrm{H}_{2} \mathrm{O}\end{array}$ \\
\hline
\end{tabular}

\section{Materials and method}

\subsection{Grape samples and winemaking}

Fetească regală grapes from Odobeşti vineyard were harvested in 2013 at optimal maturity. The grapes were destemmed and crushed, and must was transferred in glass containers. The samples was inoculated with yeasts $(30 \mathrm{~g} / \mathrm{hL})$ and processed by classical technology for obtaining white wines.

\subsection{Grape samples and winemaking}

Pluronic P123 $\left(\mathrm{EO}_{20} \mathrm{PO}_{70} \mathrm{EO}_{20}\right.$, molecular weight 5800, Aldrich) as structure directing agent, tetraethylortosilicate (TEOS 98\%, Merck) as silica source, hydrochloric acid (37\%, Merck) were used in the synthesis of mesaporous material SBA-15.

No modifications were brought to the next chemicals used for the Al-MCM-41 synthesis: cetyltrimethylammonium bromide $\left(\mathrm{C}_{16} \mathrm{H}_{3} 3\left(\mathrm{CH}_{3}\right)_{3} \mathrm{~N}^{+} \mathrm{Br}\right.$, Aldrich), tetraethylorthosilicate (TEOS, 98\% Merck) as silica source, aluminum isopropoxide (Al- $\left[\mathrm{O}-\mathrm{CH}-\left(\mathrm{CH}_{3}\right)_{2}\right]_{3}$, Merck) to generate aluminum, tetraethylammonium hydroxide $\left(\left(\mathrm{C}_{2} \mathrm{H}_{5}\right)_{4} \mathrm{NOH} 10 \%\right.$, Merck $)$ as mineralizing reagent.

No changes were applied to the tetraethylortosilicate (TEOS 98\%, Merck) as silica source, amphiphilic nonionic triblock copolymer Pluronic P123 $\left(\mathrm{EO}_{20} \mathrm{PO}_{7} 0 \mathrm{EO}_{2} 0\right.$, molecular weight 5800, Aldrich) as structure directing reagent, hydrochloric acid (37\%, Merck), n-butanol (99.4\%, Aldrich) used in the synthesis of KIT-6.

Other chemicals necessary for the GS-MS and MPAES analysis were obtained from Merck. All chemicals were used as received without supplementary purification.

\subsection{Nanomaterials synthesis}

The nanomaterials: SBA-15 [8], Al MCM-41 [9,12] and KIT-6 [10,11] were synthesized according to the literature.

Molar composition of the synthesis gel for used nanomaterials is described in Table 1:

Clinoptilolite was collected from Mârşid Romania subsoil assets (obtained from volcanic eruptions).

\subsection{Aroma compounds analysis method}

The wine samples were extracted with LiChrolut EN/RP$18(40-120 \mu \mathrm{m}) 100 \mathrm{mg}$, RP $(40-63 \mu \mathrm{m}) 200 \mathrm{mg}$ and then analyzed with Shimadzu 5 GC-2010 gaschromatograph coupled with a QP2010 Plus mass spectrometer [13].

Aroma compounds were determined by NIST 08, Wiley 08 and SZTERP libraries. All samples were analyzed in triplicate for 12 volatile compounds listed in Table 3.

\subsection{Metal content analysis}

The metallic content ( $\mathrm{Ca}, \mathrm{Mg}, \mathrm{Na}, \mathrm{Zn}, \mathrm{Fe}, \mathrm{Mn}$ ) was analyzed by microwave plasma - atomic emission spectrometry with Agilent 4200 MP-AES device. Considering cost, performance, and multi-element capabilities, the Agilent MP-AES is a suitable and efficient alternative to flame AA for this application.

\section{Results and discussion}

\subsection{Wine sample preparation}

Before fermentation four treatments were applied to the must: SBA-15, KIT-6, Clinoptilolite and AlMCM-41, when it was obtained the following variants: FR 1.1, FR 1.2, FR 1.3, the samples was treated with SBA 15 - $1 \mathrm{~g} / \mathrm{L}, 2 \mathrm{~g} / \mathrm{L}, 4 \mathrm{~g} / \mathrm{L}$; FR 2.1, FR 2.2, FR 2.3, the samples was treated with KIT-6 - $1 \mathrm{~g} / \mathrm{L}, 2 \mathrm{~g} / \mathrm{L}, 4 \mathrm{~g} / \mathrm{L}$, FR 3.1, FR 3.2, FR 3.3, the samples was treated with Clinoptilolite - $1 \mathrm{~g} / \mathrm{L}, 2 \mathrm{~g} / \mathrm{L}, 4 \mathrm{~g} / \mathrm{L}$, FR 4.1, FR 4.2, FR 4.3, the samples was treated with AlMCM-41 - $1 \mathrm{~g} / \mathrm{L}$, $2 \mathrm{~g} / \mathrm{L}, 4 \mathrm{~g} / \mathrm{L}$ and FR $\mathrm{M}-$ the blank sample, untreated. The must were stirred to ensure a homogenous fermentation. After alcoholic fermentation, wines were filtered using a filtration-filling deviceTenco Enomatic $\AA$ followed by sulfur dioxide addition $(40 \mathrm{mg} / \mathrm{L})$ to preserve wine from microbiological damage. There were other variants made after alcoholic fermentation, the wine made from the blank was bottled with SBA-15, KIT-6, clinoptilolite and AlMCM41. It was obtained the following variants: FR 5.1, FR 5.2, FR 5.3, the samples was treated with SBA 15 $1 \mathrm{~g} / \mathrm{L}, 2 \mathrm{~g} / \mathrm{L}, 4 \mathrm{~g} / \mathrm{L}$; FR 6.1, FR 6.2, FR 6.3, the samples was treated with KIT-6 - $1 \mathrm{~g} / \mathrm{L}, 2 \mathrm{~g} / \mathrm{L}, 4 \mathrm{~g} / \mathrm{L}$, FR 7.1, FR 7.2, FR 7.3, the samples was treated with Clinoptilolite $-1 \mathrm{~g} / \mathrm{L}, 2 \mathrm{~g} / \mathrm{L}, 4 \mathrm{~g} / \mathrm{L}$, FR 8.1, FR 8.2, FR 8.3, the samples was treated with AlMCM-41 - 1 g/L, 2 g/L, 4 g/L. Bottling was done with a semi-automatic device. After 12 months of storage the wines were analyzed.

\subsection{Wine volatile compounds analysis}

$70 \mathrm{~mL}$ of wine sample was filtrated through a SPE cartridge with $\mathrm{C} 18$ bed. This was first conditioned by passing $6 \mathrm{~mL}$ hexane, $6 \mathrm{~mL}$ dichloromethane, $6 \mathrm{~mL}$ ethyl acetate, $6 \mathrm{~mL}$ methanol and $6 \mathrm{~mL}$ aqueous solution with ethanol $11 \% \mathrm{v} / \mathrm{V}$. The bed was dried by passing air through it. The retained compounds were recovered by passing $2 \mathrm{~mL}$ of dichloromethane, $1000 \mu \mathrm{L}$ extract being then injected into a Shimadzu GC-2010 coupled with a mass-spectrometer QP2010 Plus.

Parameters of analysis: oven temperature: $35^{\circ} \mathrm{C}$; injector temperature: $220^{\circ} \mathrm{C}$; carrying gas: He; carrier gas speed: $1 \mathrm{~mL} / \mathrm{min}$; oven temperature program: initially, $35^{\circ} \mathrm{C}$ for 5 minutes, $4{ }^{\circ} \mathrm{C}$ per minute up to $250{ }^{\circ} \mathrm{C}$, where it stays for 13,25 minutes; ion source temperature: $250^{\circ} \mathrm{C}$; interface temperature: $250^{\circ} \mathrm{C}$; analyzed mass domain: $50-200 \mathrm{~m} / \mathrm{z}$; detector sensibility: $1.05 \mathrm{~V}$.

The influence of the used materials on wine's volatiles is represented in Table 2. Specific compounds from each of the four major chemical classes were chosen as representative. Being considered a neutral grape variety, Feteasca regala displays as identified terpene only 
Table 2. Volatiles contents of wine samples in area units.

\begin{tabular}{|c|c|c|c|c|c|c|c|c|c|c|c|c|}
\hline 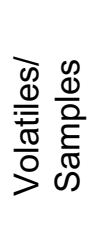 & $\begin{array}{l}\overline{0} \\
\frac{0}{\pi} \\
\stackrel{0}{5} \\
0 \\
\dot{N}\end{array}$ & 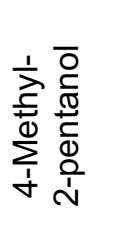 & 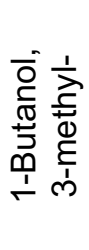 & $\begin{array}{l}\overline{0} \\
\frac{0}{\mathbb{N}} \\
\underset{0}{0} \\
\frac{1}{1} \\
\dot{N}\end{array}$ & 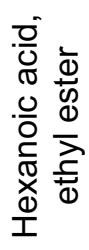 & 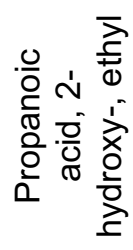 & 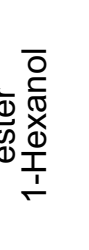 & 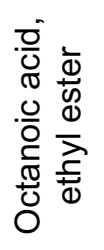 & 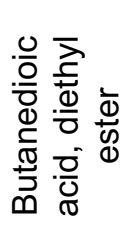 & $\begin{array}{l}\frac{0}{0} \\
\frac{\pi}{0} \\
.0 \\
\frac{0}{0} \\
\frac{\pi}{\pi} \\
\underset{x}{0} \\
\text { I }\end{array}$ & 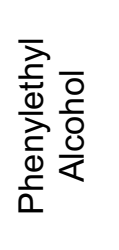 & 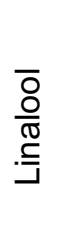 \\
\hline FR M & $\begin{array}{l}2.4 \\
10^{5}\end{array}$ & $2.810^{8}$ & $\begin{array}{l}1.2 \\
10^{8}\end{array}$ & $\begin{array}{l}2.0 \\
10^{6}\end{array}$ & $\begin{array}{l}4.1 \\
10^{5}\end{array}$ & $1.710^{6}$ & $\begin{array}{l}4.8 \\
10^{5}\end{array}$ & $\begin{array}{l}5.3 \\
10^{5}\end{array}$ & $4.210^{6}$ & $\begin{array}{l}1.4 \\
10^{6}\end{array}$ & $3.610^{6}$ & - \\
\hline $\begin{array}{l}\text { FR } \\
1.1\end{array}$ & $\begin{array}{l}1.3 \\
10^{7}\end{array}$ & $2.710^{8}$ & $\begin{array}{l}4.2 \\
10^{8}\end{array}$ & $\begin{array}{l}5.3 \\
10^{6}\end{array}$ & $\begin{array}{l}1.9 \\
10^{6}\end{array}$ & $7.910^{6}$ & $\begin{array}{l}2.6 \\
10^{6}\end{array}$ & $\begin{array}{l}1.9 \\
10^{6}\end{array}$ & $1.210^{7}$ & $\begin{array}{l}6.1 \\
10^{6}\end{array}$ & $8.110^{7}$ & $\begin{array}{l}6.4 \\
10^{5}\end{array}$ \\
\hline $\begin{array}{l}\text { FR } \\
2.1 \\
\end{array}$ & $\begin{array}{l}1.1 \\
10^{7} \\
\end{array}$ & $2.710^{8}$ & $\begin{array}{l}3.7 \\
10^{8} \\
\end{array}$ & $\begin{array}{l}5.7 \\
10^{6} \\
\end{array}$ & $\begin{array}{l}1.9 \\
10^{6} \\
\end{array}$ & $6.210^{6}$ & $\begin{array}{l}2.3 \\
10^{6} \\
\end{array}$ & $\begin{array}{l}1.7 \\
10^{6} \\
\end{array}$ & $9.810^{6}$ & $\begin{array}{l}3.8 \\
10^{6} \\
\end{array}$ & $6.610^{7}$ & $\begin{array}{l}2.2 \\
10^{5} \\
\end{array}$ \\
\hline $\begin{array}{l}\text { FR } \\
3.1\end{array}$ & $\begin{array}{l}5.3 \\
10^{6}\end{array}$ & $2.710^{8}$ & $\begin{array}{l}2.4 \\
10^{8}\end{array}$ & $\begin{array}{l}2.8 \\
10^{6}\end{array}$ & $\begin{array}{l}1.2 \\
10^{6}\end{array}$ & $3.210^{6}$ & $\begin{array}{l}1.5 \\
10^{6}\end{array}$ & $\begin{array}{l}1.4 \\
10^{6}\end{array}$ & $7.910^{6}$ & $\begin{array}{l}3.3 \\
10^{6}\end{array}$ & $5.510^{7}$ & $\begin{array}{l}2.9 \\
10^{5}\end{array}$ \\
\hline $\begin{array}{l}\text { FR } \\
4.1\end{array}$ & $\begin{array}{l}2.9 \\
10^{6}\end{array}$ & $2.710^{8}$ & $\begin{array}{l}1.6 \\
10^{8}\end{array}$ & $\begin{array}{l}2.0 \\
10^{6}\end{array}$ & $\begin{array}{l}6.7 \\
10^{5}\end{array}$ & $1.910^{6}$ & $\begin{array}{l}9.4 \\
10^{5}\end{array}$ & $\begin{array}{l}6.8 \\
10^{5}\end{array}$ & $5.010^{6}$ & $\begin{array}{l}1.7 \\
10^{6}\end{array}$ & $3.910^{7}$ & $\begin{array}{l}1.0 \\
10^{5}\end{array}$ \\
\hline $\begin{array}{l}\text { FR } \\
5.1\end{array}$ & $\begin{array}{l}3.1 \\
10^{6}\end{array}$ & $2.710^{8}$ & $\begin{array}{l}1.7 \\
10^{8}\end{array}$ & $\begin{array}{l}5.9 \\
10^{5}\end{array}$ & $\begin{array}{l}8.9 \\
10^{5}\end{array}$ & $2.210^{6}$ & $\begin{array}{l}1.0 \\
10^{6}\end{array}$ & $\begin{array}{l}1.0 \\
10^{6}\end{array}$ & $4.510^{6}$ & $\begin{array}{l}2.2 \\
10^{6}\end{array}$ & $4.110^{7}$ & $\begin{array}{l}7.3 \\
10^{5}\end{array}$ \\
\hline $\begin{array}{l}\text { FR } \\
6.1\end{array}$ & $\begin{array}{l}3.1 \\
10^{6}\end{array}$ & $2.710^{8}$ & $\begin{array}{l}1.8 \\
10^{8}\end{array}$ & $\begin{array}{l}2.8 \\
10^{6}\end{array}$ & $\begin{array}{l}9.6 \\
10^{5}\end{array}$ & $2.310^{6}$ & $\begin{array}{l}1.1 \\
10^{6}\end{array}$ & $\begin{array}{l}1.1 \\
10^{6}\end{array}$ & $5.210^{6}$ & $\begin{array}{l}2.4 \\
10^{6}\end{array}$ & $4.610^{7}$ & $\begin{array}{l}1.4 \\
10^{5}\end{array}$ \\
\hline $\begin{array}{l}\text { FR } \\
7.1\end{array}$ & $\begin{array}{l}4.6 \\
10^{6}\end{array}$ & $2.610^{8}$ & $\begin{array}{l}2.4 \\
10^{8}\end{array}$ & $\begin{array}{l}3.4 \\
10^{6}\end{array}$ & $\begin{array}{l}1.3 \\
10^{6}\end{array}$ & $3.410^{6}$ & $\begin{array}{l}1.6 \\
10^{6}\end{array}$ & $\begin{array}{c}1.4 \\
10^{6}\end{array}$ & $6.310^{6}$ & $\begin{array}{l}3.1 \\
10^{6}\end{array}$ & $5.610^{7}$ & $\begin{array}{l}3.9 \\
10^{5}\end{array}$ \\
\hline $\begin{array}{l}\text { FR } \\
8.1 \\
\end{array}$ & $\begin{array}{l}2.6 \\
10^{6} \\
\end{array}$ & $2.610^{8}$ & $\begin{array}{l}1.6 \\
10^{8}\end{array}$ & $\begin{array}{l}2.9 \\
10^{6}\end{array}$ & $\begin{array}{l}8.1 \\
10^{5}\end{array}$ & $1.910^{6}$ & $\begin{array}{l}9.3 \\
10^{5}\end{array}$ & $\begin{array}{l}8.8 \\
10^{5}\end{array}$ & $4.310^{6}$ & $\begin{array}{l}2.1 \\
10^{6}\end{array}$ & $4.110^{7}$ & - \\
\hline
\end{tabular}

Table 3. Instrumental parameters.

\begin{tabular}{|l|c|c|c|c|c|c|c|c|}
\hline Element/ Parameters & Ca & K & Mg & Na & Zn & Fe & Mn & Cu \\
\hline$\lambda(\mathbf{n m})$ & 612.222 & 693.877 & 516.732 & 330.298 & 202.548 & 259.940 & 279.827 & 318.601 \\
\hline Read Time (s) & 3 & 3 & 3 & 3 & 3 & 3 & 3 & 3 \\
\hline Nebulizer Flow (L/min) & 0.6 & 0.75 & 0.9 & 0.95 & 0.45 & 0.45 & 0.9 & 0.7 \\
\hline Air Injection Flow Rate & High & High & High & High & Medium & Medium & Medium & High \\
\hline Correlation coefficient & 0,99829 & 0.97668 & 0.99828 & 0.99689 & 0.98899 & 0.98547 & 0.95447 & 0.96991 \\
\hline
\end{tabular}

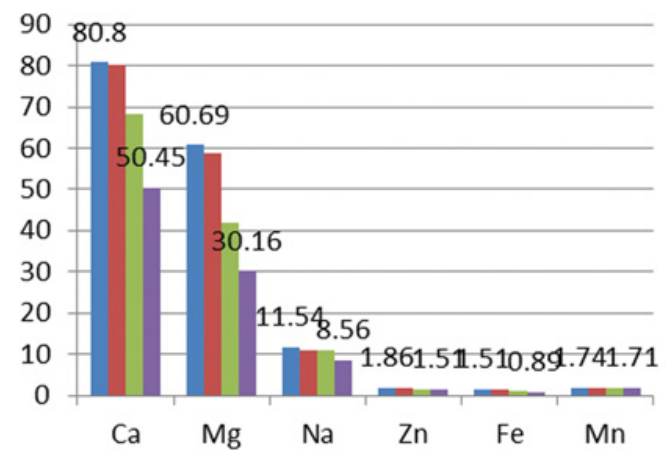

Figure 1. Variation of metals content in samples treated with SBA-15 before fermentation.

linalool, with lowest values in FR 4.1 - AlMCM-41 treatment while highest values are registered in FR 5.1 - SBA 15 treatment, applied after fermentation. Linalool is beyond the detection limit in the control sample, fact that implies that usage of micro and mesoporous materials has a positive influence on the formation of volatiles. Phenylethyl alcohol, with a rose-like odour,

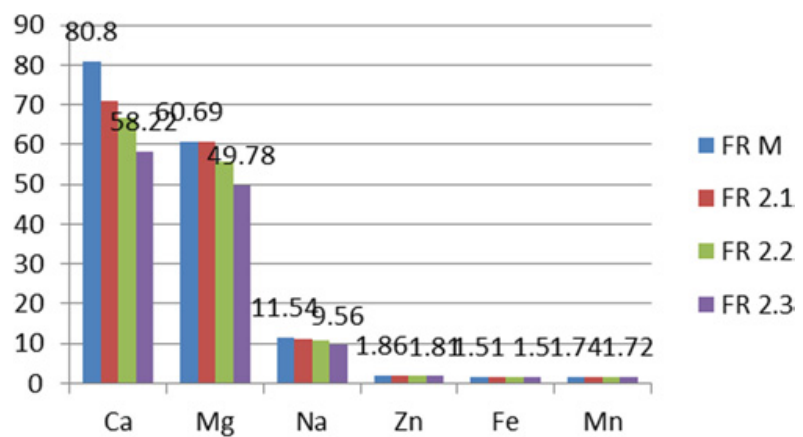

Figure 2. Variation of metals content in samples treated with KIT-6 before fermentation.

as well as 3-methyl-1-butanol register highest values in FR 1.1 - SBA 15 treatment, while lowest are recorded in the control sample. Esters of fatty acids (ethyl hexanoate and ethyl octanoate) show pleasant fruity nuances and are present in lowest values in the control sample and in highest values in FR 1.1 - SBA 15 treatment applied before fermentation. 


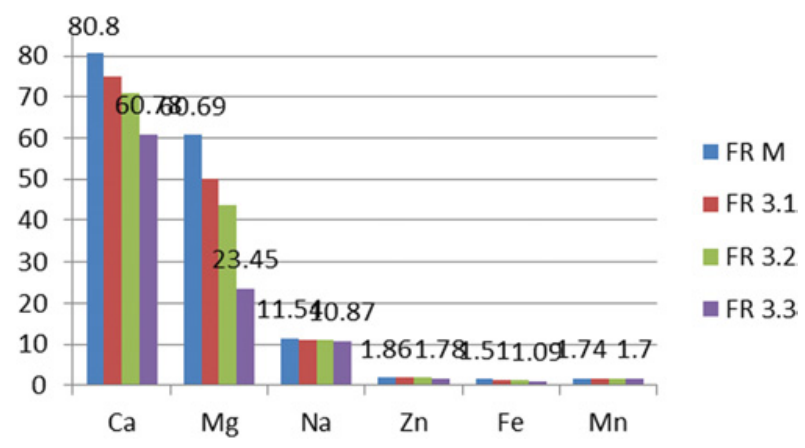

Figure 3. Variation of metals content in samples treated with Clinoptilolite before fermentation.

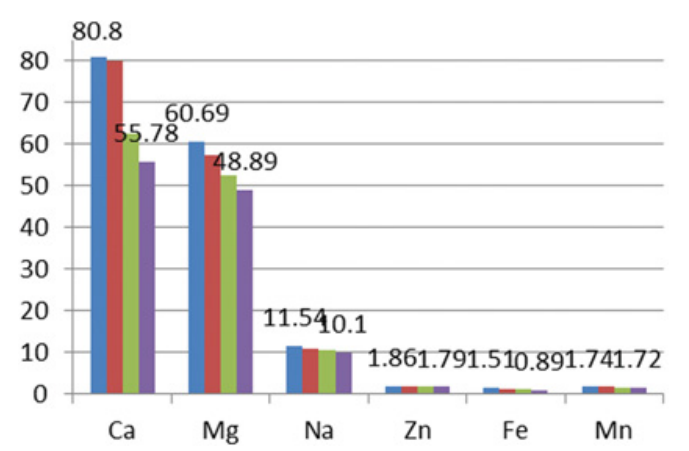

- FR M

arR 4.1

m FR 4.2

a FR 4.3

Figure 4. Variation of metals content in samples treated with AlMCM41 before fermentation.

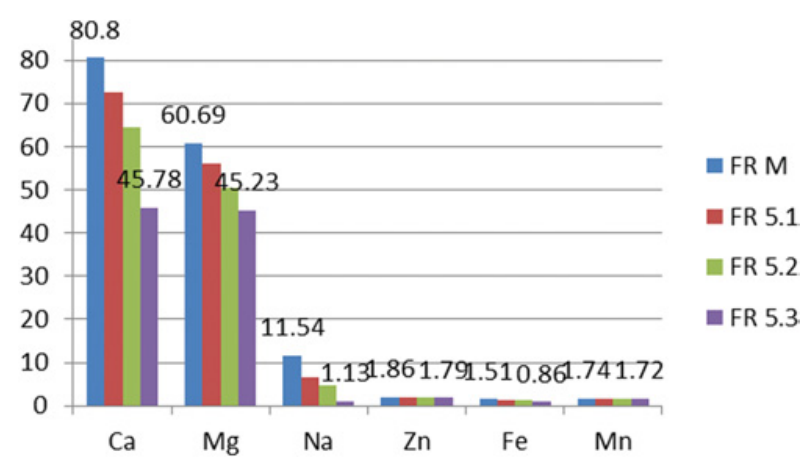

Figure 5. Variation of metals content in samples treated with SBA-15 after fermentation.

In general, the treatment with micro and mesoporous materials has a positive influence on the sensorial profile of the analysed wines.

\subsection{Metals content of wine sample}

Concentration of metals from wine was performed using an Agilent 4200 MP-AES, with nitrogen supplied from an Agilent 4107 Nitrogen Generator. The instrument was controlled by the MP Expert software. The MP-AES features continuous wavelength coverage and MP Expert features an extensive wavelength database that allows the selection of wavelengths that are appropriate for the concentration range required for the analysis.

In Table 3 are shown the operating conditions of the equipment and instrumental parameters.

The determined concentrations of metals in the examined wine samples are reported in Figs. 1-8.

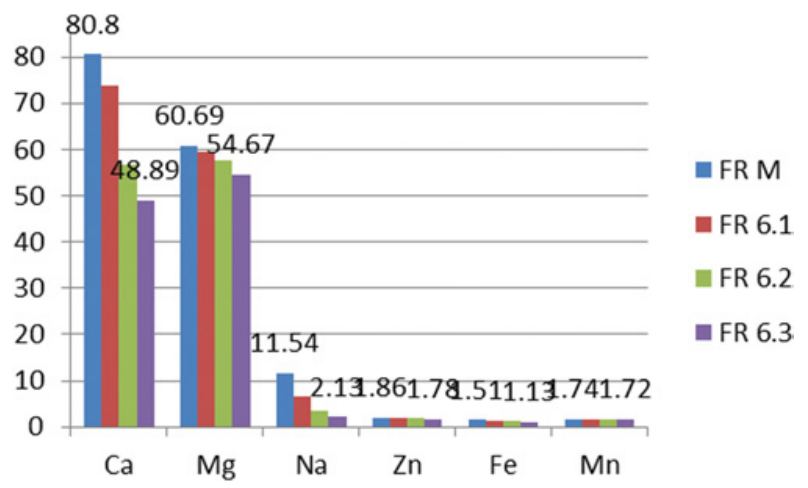

Figure 6. Variation of metals content in samples treated with KIT-6 after fermentation.

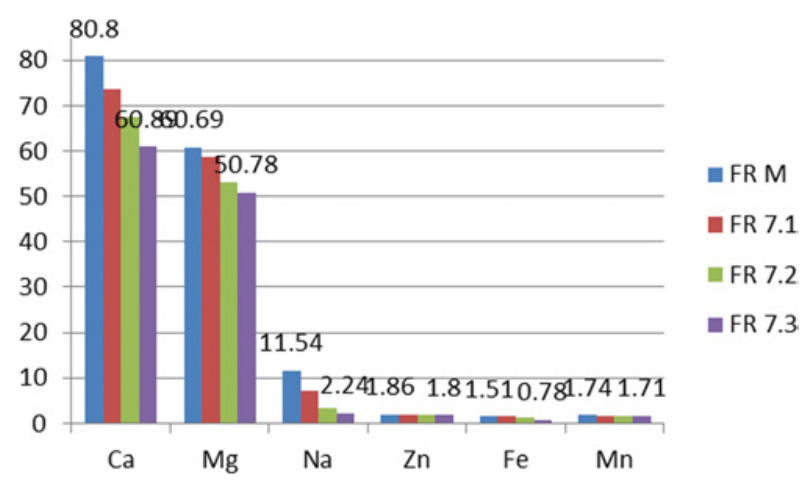

Figure 7. Variation of metals content in samples treated with Clinoptilolite after fermentation.

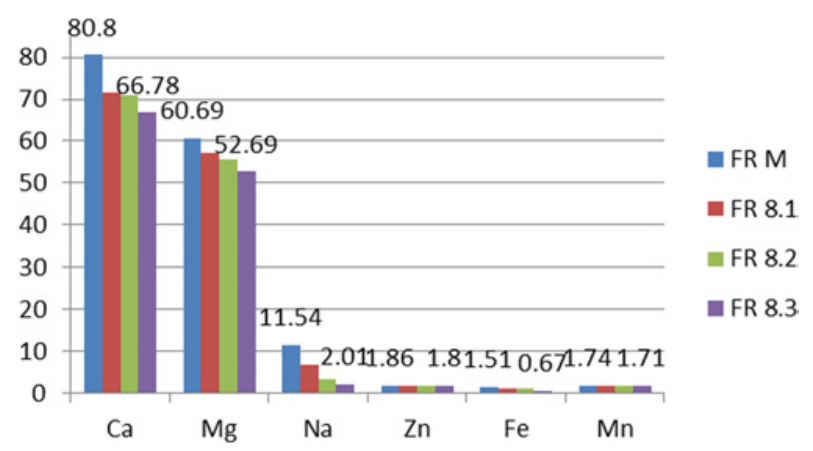

Figure 8. Variation of metals content in samples treated with AlMCM-41 after fermentation.

The measured concentrations of calcium show that these varied in range from 80.80 (control sample) to $45.78 \mathrm{mg} / \mathrm{L}$ (sample treated with SBA-15 after fermentation). Clinoptilolite treatment before fermentation reduces magnesium content of wine from 60.69 to $25.45 \mathrm{mg} / \mathrm{L}$. The amount of sodium in the analyzed samples varies between 11.54 and $2 \mathrm{mg} / \mathrm{L}$, treatments after fermentation significantly reduces the concentration of this metal in wine.

Manganese and zinc concentrations in wine are changed insignificant by applying micro and mesoporous materials treatment.

The amount of iron in the samples analyzed decreases significantly in the treated wine after fermentation with clinoptilolite and Al-MCM-41, from 1.51 up to $0.67 \mathrm{mg} / \mathrm{L}$. 


\section{Conclusions}

The applied treatments had a positive influence on volatile compounds concentration in Fetească regală samples. The content of linalool, phenylethyl alcohol and methyl-1butanol increased in treated wine samples, in control sample having the lowest concentration.

Metal content of wines and finding new methods to reduce metal concentration should be closely monitored because excess is undesirable due to potential toxicity and risks to human health. The contents of the investigated metals $\mathrm{Ca}, \mathrm{Mg}, \mathrm{Na}, \mathrm{Zn}, \mathrm{Fe}$, and $\mathrm{Mn}$ ) in wine samples treated with micro and mesoporous synthesized materials was considerably decreased.

The research was funded by the grant no. 5525 / 25.04.2013 of USAMV Iasi.

\section{References}

[1] J. Mulero, G. Martínez, J. Oliva, S. Cermeño, J.M. Cayuela, P. Zafrilla, A. Martínez-Cachá, A. Barba, Food Chem, 180, 25-31 (2015)

[2] R. S. Jackson, Chemical constituents of grape and wine, Wine Science (Fourth Edition), 347-426 (2014)
[3] M. Álvarez, I. M. Moreno, S. Pichardo, A. M. Cameán, A. G. González, Food Chem., 135, 309-313 (2012)

[4] M. P. Fabani, R. C. Arrúa, F. Vázquez, M. P. Diaz, M. V. Baroni, D. A. Wunderlin, Food Chem., 119, 372-379 (2010)

[5] M. Ortega-Heraz, M.L. González-SanJosé, S. Beltrán, Anal. Chim. Acta, 458, 85-93 (2002)

[6] V.V. Cotea, C. Luchian, N. Bilba, M. Niculaua, Anal. Chim. Acta., 732, 180-185 (2011)

[7] C. Luchian, V. V. Cotea, I. Sandu, V. Copcia, N. Bilba, Rev. chim., 62(8), $782-786$ (2011)

[8] D. Zhao, L. Feng, Q. Huo, N. Melosh, G.H. Fredrickson, B.F. Chmelka, G.D. Stucky, Sci., 279, 548-552 (1998)

[9] A. CORMA, V. FORNÉS, M.T. NAVARRO, J. PEREZ-PARIENTE, J. Catal., 148, 569-574 (1994)

[10] F. Kleitz, S. HeiChoi, R. Ryoo, - Chem. Commun., $2136(2003)$

[11] L. Xiaoying, T. Bozhi, Y. Chengzhong, G. Feng, X. Songhai, T. Bo, C. Renchao, P. Lian-Miao, Z. Dongyuan, A. Chem., 114, 4032-4034 (2002)

[12] V.E. Copcia, C.E. Luchian, N. Bilba , E.E.M.J., 9, 1243-1250 (2010)

[13] Z. Piñeiro, M. Palma, C.G. Barroso, Anal. Chim. Acta, 513, 209-214 (2004) 